FERDINAND OPLL

Uniwersytet Wiedeński

\title{
RATUSZ JAKO PRZESTRZENNE I PRAWNE CENTRUM ROZWOJU MIASTA. ROZWAŻANIA I ODNIESIENIA DO BADAŃ W NIEMCZECH I AUSTRII OD 1990 ROKU
}

Gdy mieszkajacy w Austrii historyk „wygoogluje” hasło „ratusz”, to pierwsze wyniki nie zawieraja kontekstu historycznego, lecz dotycza tematów związanych z ratuszem w Wiedniu, a dokładniej: informacji odnośnie do jego zwiedzania lub oferowanych przez Radę Miejską różnego rodzaju usług. Dopiero na trzecim miejscu wyświetla się Wikipedia, mimo wielu krytyk ciagle najpopularniejsza i wręcz nieodzowna encyklopedia ${ }^{1}$. Tu z kolei, z powodu wieloznaczności pojęcia, pod którym kryje się nie tylko budynek, lecz również administracja miejska jako taka, przekierowywani jesteśmy na osobny link „ratusz (wyjaśnienie pojęcia)"2, gdzie znajdujemy zwięzły historyczny zarys pojęcia od czasów antycznych - jako siedziby rady, czyli wyodrębnionej siedziby administracji miejskiej w starożytnej Grecji (buleuterion, wzgl. prytanejon), jak również Kurii (Curia), czyli miejsca posiedzeń senatu rzymskiego ${ }^{3}$, aż po czasy współczesne. Najwięcej miejsca poświęca Wikipedia odniesieniom do innych swoich artykułów zawierajacych informacje dotyczące starych i nowoczesnych ratuszy w Niemczech, Belgii, Danii, Francji, Islandii, Kanadzie, Lichtensteinie, Holandii, Austrii, Polsce, Szwajcarii, Słowacji i Czechach. Przedstawiona tu definicja „ratusza” ogranicza się w dużym stopniu do architektonicznego, prawnego i funkcjonalnego znaczenia terminu, bez uwzględnienia wymiaru historycznego; i brzmi ona następujacco: „Ratusz to najczęściej reprezentacyjny budynek i (główna) siedziba władzy administracyjnej powiatu lub miasta.

\footnotetext{
${ }^{1}$ http://de.wikipedia.org/wiki/Rathaus (22 IV 2013).

${ }^{2}$ http://de.wikipedia.org/wiki/Rathaus_\%28Begriffskl\%C3\%A4rung\%29(22IV2013).

${ }^{3}$ Por. D. Gneisz, Das antike Rathaus. Das griechische Bouleuterion und die frührömische Curia, Wien 1990 (Dissertationen der Universität Wien, 205).
} 
$\mathrm{Z}$ reguły jest to miejsce obrad rady miasta lub rady powiatu. W miastach-państwach służy również często jako siedziba lokalnego parlamentu”4.

$$
* * *
$$

Przyjrzyjmy się teraz innej, naprawdę naukowej i przez naukowców opracowanej encyklopedii i porównajmy zawarte w niej informacje z tymi z Wikipedii. Proszę wybaczyć autorowi, że jako mediewista wykona w tym miejscu ukłon w kierunku swojej specjalizacji i sięgnie po Lexikon des Mittelalters. Autorem znajdującej się tu definicji jest znany historyk sztuki i architektury Günther Binding, który konsekwentnie uwagę poświęca detalom architektonicznym, budowlanym i wyposażeniu ratusza jako najbardziej charakterystycznej budowli miejskiej. Zwięźle, aczkolwiek w sposób przemyślany i przekonujący, przedstawia on ratusz jako „centralny, służący przede wszystkim administracji, ale również handlowi, budynek użyteczności publicznej, siedziba i miejsce obrad rady miejskiej”5. Tym bardziej dziwny wydaje się fakt, że w opublikowanym niedawno monumentalnym dziele Eberharda Isenmanna, Die deutsche Stadt im Mittelalter 1150-1550 [Miasto niemieckie w średniowieczu 1150-1550], nie znajdziemy w indeksie pojęcia „ratusz”, a w zwiazzanym z nim przecież tematycznie obszernym rozdziale Das Stadtregiment und städtische Einrichtungen [Władze miejskie i instytucje] - żadnego właściwie opracowania na ten temat. „Rada i społeczność miejska”, „Organizacja władz ratuszowych” - te tematy oczywiście zostały poruszone ${ }^{6}$.

A przecież już sama niemiecka nazwa - Rathaus, dom rady - jasno wskazuje na funkcje ratusza jako siedziby rady, czyli przedstawicielskiego organu władzy miejskiej, do którego ukonstytuowania się prowadził zarówno rozwój prawno-historyczny, nie tylko zresztą włoskich komun miejskich, jak i - bardziej ogólnie - charakter życia miejskiego w średniowieczu. W pojęciach używanych w innych językach odnajdujemy z kolei odmienne tradycje, i tak w angielskim mówimy o town albo city hall, czyli o budynku miejskim z odpowiednio wielkim pomieszczeniem, w języku francuskim o hôtel de ville, czyli niejako o „domu miasta” (nie: rady), we włoskim używamy słów albo palazzo comunale, gdy mowa o budowli, albo municipio, gdy mowa

\footnotetext{
${ }^{4}$ Zob. przyp. 1.

${ }^{5}$ G. Binding, Rathaus, w: Lexikon des Mittelalters, t. 7, Stuttgart-Weimar 1999, s. $455-457$.

${ }^{6}$ E. Isenmann, Die deutsche Stadt im Mittelalter 1150-1550, Wien-Köln-Weimar 2012 .
} 
o administracji. Warto jednak zauważyć, że w północnowłoskich komunach na określenie wznoszonych już do XII w. własnych budynków ratuszowych obok łacińskiego terminu palatium communis używano także nazwy consularia/consolaria, która wyrażała bezpośredni związek z ustrojem konsularnym ówczesnego miasta. Polskie słowo „ratusz” z kolei jest - również dla osób niekoniecznie będących slawistami - niczym innym jak zapożyczeniem z języka niemieckiego.

Gdy na obszarach niemieckojęzycznych zaczęto wznosić ratusze - już we wczesnym okresie rozwoju miejskiego, czyli od 2. połowy XIII w., ale na większą skalę dopiero od XIV, XV w., a także później, w epoce wczesnonowożytnej - był to bez wątpienia wyraźny dowód na to, że mieszczaństwo uczyniło zasadniczy skok samoświadomościowy, i na postęp w kształtowaniu przez nie odpowiedzialności politycznej. Stało się ono decydujacym partnerem $\mathrm{w}$ rozstrzygnięciach politycznych dotyczących istotnych spraw życia miejskiego. Do powstawania ratuszy dochodziło w różny sposób, przy czym szczególnie we wczesnym okresie najczęściej przekształcano w ratusze budynki już istniejące. Przywołany przez Bindinga jako najstarszy niemiecki - ratusz w Gelnhausen przy Rynku Dolnym nie został wybudowany jako ratusz, lecz jako siedziba villicusa w powołanym do życia przez cesarza Fryderyka Barbarossę około 1170 r. ośrodku miejskim ${ }^{7}$.

Przykład ten wręcz skłania do dociekań, kiedy właściwie pojawiły się ratusze i które miasto może poszczycić się ratuszem najstarszym. Można nawet mówić o „współzawodnictwie między miastami” na tym polu i rzecz jasna nauki ściśle historyczne niewiele mają tu do powiedzenia, jako że bliższe jest ono agresywnej kampanii reklamowej. I tak w Wikipedii pod hasłem Palazzo della Ragione w Bergamo znajdujemy powołujace się na przewodnik turystyczny wyjaśnienie, że tamtejszy ratusz - powstały między 1183 i 1198 r. - jest najstarszym „pałacem komunalnym” we Włoszech ${ }^{8}$. Natomiast gdy przestudiujemy dokładniej historię włoskiego miasta Lodi, to przekonamy się, że tamtejsza consolaria wzmiankowana jest już około 1165 r. ${ }^{9}$ Jeżeli chodzi o niemiecki obszar językowy, to Gelnhausen może służyć jako bardzo wczesny

${ }^{7}$ G. Binding, Rathaus..., s. 455.

${ }^{8}$ http://it.wikipedia.org/wiki/Palazzo_della_Ragione_\%28Bergamo\%29 (22 IV 2013);

o tu cytowanym przewodniku zob. http://guide.travelitalia.com/it/guide/bergamo/ palazzo-vecchio-o-della-ragione-verona/ (22 IV 2013).

${ }^{9}$ F. Opll, Städtegründungen des hohen Mittelalters - Überlegungen anhand der lombardischen Stadt Lodi, w: Stadtgründung und Stadtwerdung. Beiträge von Archäologie und Stadtgeschichtsforschung, red. F. Opll, Linz 2011 (Beiträge zur Geschichte der Städte Mitteleuropas, 220), s. 306, 320. 
przykład budowlano-architektoniczny, ale ratusz koloński udokumentowany jest jeszcze wcześniej, przed 1150 r., co podkreśla wysoką rangę Kolonii w niemieckim życiu miejskim ${ }^{10}$.

W rozważaniach nad naszym tematem musimy zwrócić uwagę na sytuację we Włoszech, szczególnie północnych, gdzie rozwój życia miejskiego, najogólniej rzecz biorąc, świętował swoje wzloty najwcześniej. By nie wdawać się zbytnio w szczegóły, zwróćmy się ponownie ku terminologicznej stronie owego rozwoju. Chociaż nie da się stwierdzić ze stuprocentowa pewnościa, które $\mathrm{z}$ zachowanych określeń ratusza jest najstarsze, to jednak termin broletto odnosi się, jak się wydaje, do okresu najwcześniejszego. Jego pierwotne znaczenie - „ogrodzona wolna powierzchnia" - może wskazywać na place zgromadzeń pod gołym niebem, które to place ze względu na doniosłość zapadających tam decyzji miały szczególny status prawny ${ }^{11}$. Termin ten używany jest na określenie ratuszy w Brescii (Palazzo Broletto, przed 1187/1189 r.), w Pawii (XII w.) czy w Mediolanie, gdzie Broletto Nuovo z 1233 r. stanowiło centrum administracji miejskiej. Dodatek arengario, a więc broletto arengario, występuje również samodzielnie (np. w Monzy, XIII w.) ${ }^{12}$ i wskazuje na pochodzące z germańskiego słowo (h)ring (Ring, Kreis - „pierścień”, „koło”), używane prawdopodobnie na określenie placu w kształcie koła, na którym odbywały się zgromadzenia. Innego zabarwienia znaczeniowego, a mianowicie związanego z charakterystycznym dla epoki budownictwem miejskim w kształcie palazzi, dostarcza nam trochę młodszy termin palatium communis (wł. palazzo comunale); zaś termin consolaria civitatis nove Laude, który poświadczony jest już w 1165 r. w odniesieniu do nowo lokowanego w 1158 r. miasta Lodi, podkreśla bezpośrednie połączenie funkcji miejsca obrad oraz siedziby zarówno rady miejskiej, jak i administracji. Mądre rządy nad miastem znajduja swoje bezpośrednie odbicie $\mathrm{w}$ pojawiającym się od XIII w. określeniu palazzo della ragione $e^{13}$, a doskonałe architektoniczne

\footnotetext{
${ }^{10} \mathrm{http} / / /$ de.wikipedia.org/wiki/Rathaus_K\%C3\%B6ln (22 IV 2013).

${ }^{11}$ Zob. np. http://de.wikipedia.org/wiki/Broletto (22 IV 2013).

${ }^{12}$ http://it.wikipedia.org/wiki/Arengario_di_Monza (22 IV 2013).

${ }^{13}$ Termin ragione $\mathrm{w}$ odniesieniu do budynku (pomieszczenia) oznaczał siedzibe wymiaru sprawiedliwości, rzadziej - miejsce zebrań „parlamentu”. Nazwa palazzo della ragione, rozpowszechniona na przełomie średniowiecza i epoki nowożytnej w północnych Włoszech, a dziś kojarzona przede wszystkim ze wspaniałą budowlą padewską (wzniesiona w XIII w. jako palatium Paduae, palatium Paduanum, i przebudowana w początkach XIV w.), najczęściej zastępowała w miastach zdobytych przez Wenecję dawną nazwę pałacu komunalnego, określając przede wszystkim siedzibę trybunałów sądowych dawnych suwerennych komun (republik), teraz o mocno okrojonej niezależności (przyp. red.).
} 
przykłady takich pałaców znajdujemy w Padwie i Vicenzy. Na zmieniające się po $1200 \mathrm{r}$. uwarunkowania ustrojowe wskazuja terminy takie jak palazzo del podestà czy palazzo della signoria ${ }^{14}$.

Wróćmy teraz do niemieckiego obszaru językowego i do sytuacji na północ od Alp. Tak jak w przypadku rozwoju miasta w kierunku politycznie i prawnie niezależnego organizmu, o którym w sposób znaczący współdecydowali jego mieszkańcy, tak i w przypadku pojawiania się ratuszy zauważyć można znaczne opóźnienie w stosunku do obszaru włoskiego. Owszem, w wielkich i znaczących ośrodkach miejskich, gdzie głos mieszczaństwa liczył się już i we wczesnym okresie, znaleźć można sporadycznie nawet w XII w. budynki, w których zbierali się mieszczanie, zajmowali się sprawami ważnymi dla miasta i piastowali przy tym różne godności; a jednak na szerszą skalę dopiero w XIV, XV w. ratusze stały się integralną częścią zabudowy miejskiej. Niech będzie mi tu wolno, jako osobie pochodzącej z Wiednia, zwrócić uwagę na stosunkowo wczesny, obok Kolonii, przykład miejskiej budowli ratuszowej, a mianowicie ratusz wiedeński. Dzieje tzw. Starego Ratusza (Das Alte Rathaus) sa szczególnie dobrze udokumentowane. Chodzi tu o budynek skonfiskowany przez księcia habsburskiego po rebelii szlachty, darowany przezeń miastu na wniosek mieszczan wiedeńskich wraz z dokumentem nadania w 1316 r., zachowanym do dziś w oryginale. Nie wiemy jednak nic o wykorzystaniu tego budynku jako ratusza w początkowym okresie, mimo jego doskonałej lokalizacji, tzn. niedaleko Wysokiego Rynku, czyli w centrum gospodarczym miasta. Wzmianki o nim znajdujemy dopiero na poczatku lat 40. XIV stulecia. W 1990 r. przypadkowe znalezisko w zbiorach Archiwum Korony Aragońskiej w Barcelonie potwierdziło istnienie o wiele starszego ratusza w Wiedniu: w związku z zapoczątkowanymi w 1311/1312 rokowaniami w sprawie ślubu austriackiego księcia Fryderyka Pięknego z Izabela, córką króla Aragonii Jakuba II, miasta austriackie pod przewodnictwem Wiednia wydały pewnego rodzaju poświadczenie gwarancji, które spisane zostało $26 \mathrm{~V} 1313$ r.: ,apud domum communis ubi more solito ad sonum preconis sunt assueti universitatis nomine congregari”. Dalsze badania wykazały w końcu, że chodzi tu o budynek na Wollzeile, naprzeciwko plebanii, i że można znaleźć potwierdzenie jego jeszcze wcześniejszego istnienia, tzn. już około $1288 \mathrm{r} .^{15}$

${ }^{14} \mathrm{O}$ terminologii zob. H. Manikowska, Od domus civium do pałacu komunalnego. Średniowieczne poczatki siedziby władz miejskich, w niniejszym tomie.

${ }^{15}$ F. Opll, Das älteste Wiener Rathaus, „Jahrbuch des Vereins für Geschichte der Stadt Wien" 46, 1990, s. 107-122; o ratuszu użytkowanym obecnie jako siedziba władz 1. dzielnicy Wiednia zob.: G. Buchinger, D. Schön, Das alte Rathaus. Die bauliche 
Posiadane przez nas dokumenty pozwalają stwierdzić istnienie ratuszy $\mathrm{w}$ miastach niemieckiego obszaru językowego z reguły dopiero pod koniec późnego średniowiecza. Mimo że rozchodzi się tu zawsze o termini ante quem i precyzyjny czas wzniesienia danych obiektów jest trudny do określenia, to można przyjąć, że ich powstanie nie jest zbytnio odległe w czasie od pierwszej o nich wzmianki. Szerzej zakrojone badania historii miast niemieckich istotnie ułatwiłyby dalsze analizy porównawcze, niestety nie są możliwe z powodu niesatysfakcjonującego stanu zachowania i dostępności źródeł ${ }^{16}$. Jeżeli chodzi o miasta austriackie, to Der Österreichische Städteatlas (Austriacki atlas miast) w wydaniu DVD (2009 r.) ${ }^{17}$ umożliwia dalsze poszukiwania $\mathrm{z}$ wykorzystaniem techniki cyfrowej. Bez głębszej analizy zestawionych tu 59 miast można ustalić, że z wyjątkiem wspomnianego już ratusza w Wiedniu wszystkie pozostałe ratusze austriackich miast nie dają się udokumentować przed XIV w. Najstarsze znajduja się w Enns, Freistadt, Hainburgu, Innsbrucku i Krems, a w XV w. dochodzi jeszcze wiele innych miast, jak Gmunden, Klagenfurt, Korneuburg, Linz, Radstadt, Steyr, Tulln, Weitra, Wels, Wiener Neustadt i Zwettl. Jeśli chodzi o uchwytna tu chronologię, to należy przyjąć, że pierwsze wzmianki pojawiające się na początku nowego stulecia, tak jak ma to miejsce w przypadku Wiener Neustadt w 1401 r. czy Judenburgu w 1501, wskazuja z dużym prawdopodobieństwem na istnienie danych obiektów już w wieku poprzednim. Do dzisiaj datuje się ratusze częściej na podstawie badań architektoniczno-budowlanych niż w oparciu o najstarsze dokumenty, które wskazywałyby na ówczesną funkcję budynku - co nie ułatwia sprawy.

Musimy wprowadzić tu rozróżnienie między, po pierwsze, zmianą funkcji istniejących już budynków (tzn. przekształcenia ich w ratusze, tak jak miało to miejsce $\mathrm{w}$ przypadku ratusza $\mathrm{w}$ Waidhofen an der Ybbs, który to budynek od 1355 r. służył miastu jako „dom kupiecki” i gdzie mieszczanie mieli możliwość kontroli nad różnego rodzaju transakcjami i interesami, a który dopiero od 1639 r. funkcjonował jako ratusz), a - po drugie - nowym budynkiem. Takowa inicjatywa budowlana - jak w przydatku miasta Steyr - miała o wiele donioślejsze znaczenie prawne i polityczne dla rozwoju miasta. Wielokrotnie w czasie tego rodzaju przedsięwzięć budowlanych miasta mogły korzystać ze

Genese eines Wiener Monumentalbaus, „Österreichische Zeitschrift für Kunst und Denkmalpflege" 56, 2002, nr 4, s. 420-443.

${ }^{16}$ Zob. http://www.uni-muenster.de/Staedtegeschichte/projekte/Dt_Staedtebuch_Detail.html (22 IV 2013).

${ }_{17}$ Österreichischer Städteatlas, t. 1-10, red. F. Czeike, R. Banik-Schweitzer, F. Opll, A. Weigl, Wien 1982-2008. DVD (Arcanum Adatbázis Kft., Budapest [2009]). 
wspaniałomyślności książąt - obok Wiednia można tu jeszcze wymienić Enns i Klagenfurt, a więc miasta, którym cesarz Fryderyk III w tym samym roku, a mianowicie 1489, podarował budynek pod przyszły ratusz. Jeżeli chodzi o teren Austrii, to możemy chyba i tu przyjąć tezę, że wyraźna utrata autonomii miast z początkiem ery nowożytnej pociagała za sobą coraz bardziej słabnąca inicjatywę w kwestii budowy własnych ratuszy. W kontekście „zleconej samorządności” (beauftragte Selbstverwaltung), jak określiła to wykładająca we Frankfurcie historyk Luise Schorn-Schütte w swoim wydanym w 1976 r. studium, dla tego rodzaju miejskich przedsięwzięć budowlanych nie było praktycznie miejsca ${ }^{18}$.

Inną kwestia zasługująca tu na najwyższą uwagę jest lokalizacja ratusza. Duże znaczenie ma to, czy ratusz jest usytuowany pośrodku miasta, czy w oddaleniu od centrum, na rynku, względnie centralnym placu, a tym samym w newralgicznym miejscu gospodarczego życia miasta, czy też w pobliżu kościoła, stanowiąc tym samym przeciwwagę dla duchowego życia miasta. W kontekście charakterystycznej dla epoki renesansu koncepcji „miasta idealnego” w przeważającej większości mamy do czynienia z sytuacja, gdy ratusz znajdował się na centralnym placu miasta, oczywiście obok „kościoła-katedry”, „,szkoły łacińskiej” i „zbrojowni”. I znowu, informacje zawarte w europejskich atlasach miast dostarczaja nam istotnych przesłanek do tego rodzaju analiz przestrzennych ${ }^{19}$. Należy więc powtórzyć częsty apel wydawców tych atlasów, by posługiwać się zawartymi w nich materiałami topograficznymi w badaniach porównawczych nad historią miast. Wiele wskazówek dostarcza nam tutaj Der Österreichische Städteatlas.

Przyjrzyjmy się wynikom tych badań. Austriackie ratusze w przeważającej części usytuowane są centralnie przy głównych placach czy rynkach lub nawet na środku takowych placów. Tylko w nielicznych przypadkach wykazano lokalizację w pobliżu religijnego centrum miasta, ale nawet wtedy ich usytuowanie pozostawało w ścisłym związku ze szlakami komunikacyjnymi i handlowymi (Wiedeń, Freistadt). Dalszy rozwój miast kładł często kres sasiedztwu ratusza i plebanii, przenoszono bowiem

${ }^{18}$ L. Schorn-Schütte, Von der autonomen zur beauftragten Selbstverwaltung. Die Integration der deutschen Stadt in den Territorialstaat am Beispiel der Verwaltungsgeschichte von Osnabrück und Göttingen in der Frühen Neuzeit, „Osnabrücker Mitteilungen. Mitteilungen des Vereins für Geschichte und Landeskunde von Osnabrück” 82, 1976, s. 29-59.

${ }^{19}$ Por. M. Scheutz, Die Multifunktionalität der Rathäuser in langer Perspektive. Versuch eines Überblicks, w: Rathäuser als multifunktionale Räume der Repräsentation, der Parteiungen und des Geheimnisses, red. S.C. Pils, M. Scheutz, C. Sonnlechner, S. Spevak, Innsbruck-Wien-Bozen 2012 (Forschungen und Beiträge zur Wiener Stadtgeschichte, 55), s. 32. 
siedzibę władz miejskich w pobliże placów i rynków o większym znaczeniu gospodarczym. Można więc chyba przyjąć za regułę, że typowe usytuowanie ratusza to bezpośrednie pobliże rynku, bardzo często skrzyżowanie najważniejszych dróg miejskich prowadzących prosto od bram lub wręcz sam środek rynku.

Fakt ten koresponduje ze znaczeniem, jakie miały w początkach rozwoju miejskiego regulacje dotyczące funkcjonowania rynku. Mieszczanie wcześnie zaczęli zabiegać o prawo do współstanowienia i współdecydowania w kwestiach aprowizacji mieszkańców i rozwoju gospodarczego. Obok sądownictwa, w które to mieszczaństwo już od wczesnego okresu angażowało się poprzez funkcje ławników lub podobne instytucje, właśnie gospodarka stanowiła najistotniejsze pole aktywności miejskiej. Kilka przykładów potwierdza to zjawisko. Tak jak niekiedy ratusze wchłaniały miejsce sądu, Schranne (Mödling), czy wykorzystywały dawne „domy kupieckie” (Waidhofen an der Ybbs), tak też one same służyły nierzadko innym celom: jako miejsce przechowywania wagi miejskiej, broni lub jako magazyn na zboże i sól. W naprawdę wielkich ośrodkach miejskich, jak np. we Wiedniu, funkcje te spełniały z reguły osobne, przeznaczone specjalnie do tych celów budynki.

Zanim przejdziemy do przeglądu literatury przedmiotu poświęconej zjawisku ratusza, zwróćmy jeszcze uwagę na inne potencjalne pola badawcze, którymi do tej pory w istocie się jeszcze nie zajmowano. Oprócz szczegółowych dla każdego miasta badań nad położeniem topograficznym ratusza brakuje także studiów nad istotna jego częścia, a mianowicie jego wieża. Była ona nie tylko szczególnie doniosłym symbolem władzy i pozycji miasta, lecz również miejscem, na którym umieszczano zegar jako znak panowania nad czasem. Z racji swej masywności i solidności wykonania była najlepiej zabezpieczona częścią całej budowli, znajdowały się tu więzienia, przechowywano różnego rodzaju akty prawne, urządzano archiwum. Zwróćmy wreszcie uwagę i na to, że tematu ratuszy w żadnym razie nie wolno ograniczyć do epoki średniowiecza i wczesnej nowożytności. Oto w XIX w. - równolegle do odradzającej się ponownie autonomii miast - odnotowujemy w wielu niemieckich ośrodkach miejskich swego rodzaju „boom budowlany” jeżeli chodzi o ratusze oraz porównywalna tendencję w czasach współczesnych, szczególnie od 2. połowy XX w., kiedy zaczęto budować nowe ratusze - tym razem zapewne z powodu powiększenia się obszarów miejskich i potrzeby ich uporządkowania ${ }^{20}$.

${ }^{20}$ Przykładem jest rozpoczęta w 1985 r. budowa ratusza w Linzu nad północnym brzegiem Dunaju, poza historycznym obszarem miasta, zob. http://de.wikipedia.org/ wiki/Neues_Rathaus_\%28Linz\%29 (22 IV 2013). 
W przeglądzie badań związanych z problematyką ratusza na niemieckojęzycznym obszarze możemy na szczęście oprzeć się na wydanej niedawno pracy zbiorowej - pokłosiu konferencji, która odbyła się w październiku 2011 r. we Wiedniu. Jeden z wydawców tej publikacji, Martin Scheutz, zajał się w swoim artykule kwestią wielofunkcyjności ratuszy w długiej perspektywie czasowej (Multifunktionalität der Rathäuser in langer Perspektive) ${ }^{21}$, dając zarazem bardzo szeroki przegląd wyników dotychczasowych badań nad tematem. Prezentowane tu przeze mnie wywody i przemyślenia opierają się w znacznym stopniu na wywodach Scheutza.

Jeden fakt zasługuje na szczególną uwagę, a mianowicie to, że ratusze do tej pory stanowiły przedmiot pojedynczych badań w odniesieniu zawsze do jednego konkretnego miasta, prowadzonych bardzo często na jego zlecenie. Ratusz, bez wattpienia najbardziej doniosła budowla świecka w strukturze miejskiej od późnego średniowiecza, w XIX w. jako szczególnie monumentalny w swej formie okazały gmach, a w XX, XXI w. jako dostosowany architektonicznie do ducha czasu nowoczesny obiekt użyteczności publicznej, zdefiniowany został w 1718 r. przez Leonharda Christopha Sturma, teoretyka architektury okresu baroku, następująco: „Okazały budynek publiczny / gdzie radni miasta, a czasami też reprezentanci mieszczaństwa / debatowali nad sprawami wspólnymi dla wszystkich" ${ }^{22}$. Akcentowanie w badaniach symboliki i bogactwa wyposażenia tej centralnej dla miasta budowli - z wyjątkiem ratuszy z małych i średnich miast z przełomu późnego średniowiecza i początków ery nowożytnej - związane jest $\mathrm{z}$ faktem, że zajmowali się nimi (i nadal zajmuja) badacze z dziedziny historii sztuki, traktując historię ratuszy głównie z perspektywy dzieła sztuki i architektury. Już na wstępie podkreślone zostało, że autorem definicji „ratusza” pochodzącej ze sztandarowego Lexikon des Mittelalters jest Günther Bin$\operatorname{ding}^{23}$, a więc historyk sztuki. Dodajmy tu jeszcze, ujmując literaturę przedmiotu w dłuższej perspektywie czasowej, następujące pozycje: Das deutsche Rathaus der Renaissance [Niemiecki ratusz epoki renesansu], prace niemieckiego historyka sztuki Augusta Grisebacha wydana w 1907 r., album Rudolfa Dellinga z 1958 r. i berlińską dysertację Christy Schreiber o „ratuszach z epoki baroku we Frankonii, Szwabii i Badenii” (Rathäuser des Barock in Franken, Schwaben und Baden) ${ }^{24}$.

\footnotetext{
${ }^{21}$ Zob. przyp. 19.

${ }^{22}$ Cyt. za: M. Scheutz, Multifunktionalität der Rathäuser..., s. 19.

${ }^{23}$ Zob. przyp. 5.

${ }^{24}$ A. Grisebach, Das deutsche Rathaus der Renaissance, Berlin 1907; R. Delling, Deutsche Rathäuser, Frankfurt am Main 1958; C. Schreiber, Rathäuser des Barock in Franken, Schwaben und Baden, Berlin 1973.
} 
Jeżeli chodzi o nauki związane $\mathrm{z}$ historia budownictwa i renowacji zabytków, to dysponujemy również publikacjami na nasz temat, jak chociażby wydaną w 2003 r. książką Ursuli Schädler-Staub i Angeli Weyer z Hochschule für Angewandte Wissenschaft und Kunst (Hildesheim / Holzminden / Getynga) o średniowiecznych ratuszach w Dolnej Saksonii i Bremie ${ }^{25}$. Historię sztuki, a dokładniej historię sztuki średniowiecznej reprezentuje ponadto wykładajacy w Bambergu Stephan Albrecht, będący autorem szeregu publikacji na temat różnych ratuszy, m.in. opublikowanego w 2004 r. tomu Mittelalterliche Rathäuser in Deutschland ${ }^{26}$ czy studium z 2010 r. Stadtgestalt und Öffentlichkeit ${ }^{27}$, w którym zwraca szczególną uwagę na przestrzenie miejskie mające znaczenie polityczne. W końcu 2010 r. ukazał się znakomity zbiór tekstów - Public Buildings in Early Modern Europe ${ }^{28}$, będący owocem dwóch międzynarodowych konferencji zorganizowanych w Utrechcie w 2006 i 2008 r., zredagowany przez Koen Ottenheym - wykładowcę historii architektury na uniwersytecie w Utrechcie ${ }^{29}$, Monique Chatenet - główna konserwator dziedzictwa kulturowego i profesor paryskiej Sorbony ${ }^{30}$, i Kristy de Jonge z wydziału architektury, budownictwa i planowania miejskiego belgijskiego uniwersytetu w Lowanium. Druga część tej publikacji poświęcona jest tematowi Government and Justice. Osiem z jedenastu artykułów składających się na tę część porusza temat ratuszy, trzy pozostałe zajmuja się wojskowymi budynkami administracyjnymi (Hôtel de l'Intendance) w XVIII w. we Francji, państwowymi więzieniami w Neapolu i Wenecji w XVI w. i dwoma zakładami poprawczymi w Amsterdamie. Ogólnie rzecz biorąc, mamy tu do czynienia ze znakomitym zbiorem case studies, wśród których sa zaprezentowane także badania wspomnianego już wcześniej niemieckiego historyka sztuki Albrechta w artykule Against Building Typology. Why a Town Hall doesn't have to

${ }^{25}$ U. Schädler-Staub, A. Weyer, Mittelalterliche Rathäuser in Niedersachsen und Bremen. Geschichte - Kunst - Erhaltung, Petersberg 2003 (Schriften des Hornemann Instituts, 6; Regionale Kulturerbe-Routen, 2).

${ }^{26}$ S. Albrecht, Mittelalterliche Rathäuser in Deutschland. Architektur und Funktion, Darmstadt 2004.

${ }_{27}$ Tenże, Stadtgestalt und Öffentlichkeit. Entstehung, Nutzung und Gestaltung von Stadtzentren in Mittelalter und Früher Neuzeit, Köln 2010.

${ }^{28}$ Public Buildings in Early Modern Europe, red. K. Ottenheym, M. Chatenet, K. de Jonge, Turnhout 2010 (Architectura Moderna, 9). Por. też recenzję J. Jachmanna z tego tomu: http://www.sehepunkte.de/2011/09/19402.html (22 IV 2013).

${ }^{29}$ Zob. http://www.uu.nl/gw/medewerkers/KAOttenheym (22 IV 2013).

${ }^{30}$ Zob. http://chateauversailles-recherche.fr/IMG/pdf/Monique_Chatenet_1_.pdf (22 IV 2013). 
look like a Town Hall. A Case Study on the Town Halls of Augsburg and Nuremberg ${ }^{31}$.

Przedstawiciele nauk historycznych zajmuja się zazwyczaj - i to w przeważającej większości - historią ratusza jakiegoś konkretnego miasta. Wśród nich znajduja się osoby piastujące prominentne stanowiska w konkretnym archiwum miejskim, jak np. Felix Czeike, kierownik Wiedeńskiego Archiwum Miejskiego i Krajowego w latach 1976-1989, czy Franz-Heinz Hye, dyrektor Archiwum Miejskiego w Innsbrucku w latach 1969-1998. Badacze ci są autorami studiów na temat ratuszy (odpowiednio) w Wiedniu ${ }^{32}$ i Innsbrucku ${ }^{33}$. Budowa lub przebudowa ratusza, lub jego jubileusz stają się zawsze doskonałą okazją do powstawania stosownych publikacji. Abstrahujac jednak od takich sytuacji, zawsze mile widziane sa przez każde miasto nowe publikacje dotyczące jego własnego ratusza, oczywiście gdy ukazują się w rozsądnych odstępach czasowych. Problematyka ratuszy jest więc w pewnym sensie głównym tematem dla publikacji subwencjonowanych przez miasto, co nie zawsze idzie $\mathrm{w}$ parze $\mathrm{z}$ rzetelnością naukowa.

Za sprawą badaczy, którzy na zasadzie cross over poruszają się między dziedzina historii a dziedziną historii sztuki - nie tylko przyjmując punkty widzenia obu dyscyplin, ale również wykorzystując możliwości, jakie daje ich połączenie - studia nad ratuszami zyskały w ostatnich latach nowy wymiar, charakteryzujacy się przeniesieniem punktu ciężkości bardziej w stronę dociekań historycznych. Przykładem takich badaczy może być tutaj wykładajaccy w Zurychu historyk Bernd Roeck, specjalista z zakresu wczesnej epoki nowożytnej, który wraz z dwoma kolegami w 1985 r., w katalogu wydanym z okazji jubileuszu ratusza w Augsburgu (1385-1985), złożył tej znakomitej renesansowej budowli obszerny naukowy hołd ${ }^{34}$. W latach 90 . XX w. ukazały się dwa kolejne artykuły jego autorstwa, w których ponownie poświęcił uwagę ratuszowi, tym razem w szerzej zakrojonym kontekście ${ }^{35}$.

\footnotetext{
${ }^{31}$ Public Buildings..., s. 93-104.

${ }^{32}$ F. Czeike, Das Rathaus, Wien-Hamburg 1972 (Wiener Geschichtsbücher, 12).

${ }^{33}$ Por. F.-H. Hye, Geschichte der Stadt Innsbruck. Gesammelte Aufsätze und Beiträge, CD-ROM (Innsbruck Link Interactive Systems 2001).

${ }^{34}$ Elias Holl und das Augsburger Rathaus. Eine Ausstellung der Stadt Augsburg, Stadtarchiv, 22. Juni - 1. September 1985, red. W. Baer, H.-W. Kruft, B. Roeck, Regensburg 1985.

${ }^{35}$ B. Roeck, Rathaus und Reichsstadt, w: Stadt und Repräsentation, red. B. Kirchgässner, H.-P. Becht, Sigmaringen 1995 (Stadt in der Geschichte, 21), s. 93-114; tenże, Reichsstädtische Rathäuser in der frühen Neuzeit und ihre Bildprogramme, w: Bilder des Reiches, red. R.A. Müller, Sigmaringen 1997 (Irseer Schriften, 4), s. 275-296.
} 
Choć w dziedzinie nauk historycznych indywidualne przedsięwzięcia i zainteresowania cieszą się zawsze uznaniem, to jednak bez porównania większe znaczenie ma rozważanie, badanie i analizowanie zjawisk historycznych z innej perspektywy, z innego punktu widzenia niż czynione to było do tej pory, zwłaszcza że w ciagu ostatnich 30 lat dochodziło tak często do zmian paradygmatów. Wspomnieć tu należy przede wszystkim trzy takie zwroty w nauce: (1) nowy punkt widzenia objawiający się $\mathrm{w}$ nurcie pictorial turn, w ramach którego badania historyczne powinny silniej niż do tej pory korzystać ze źródeł obrazowych, biorąc również pod uwagę ich powstanie i oddziaływanie ${ }^{36}$; (2) nowe możliwości, które niesie ze sobą nurt spatial turn, który przypisuje decydujące znaczenie czynnikom przestrzennym ${ }^{37}$; i wreszcie (3) badania nad zjawiskiem komunikacji społecznej ${ }^{38}$. W sposób szczególnie inspirujacy przedstawia to Martin Scheutz, gdy określa ratusz nie tylko jako ceremonialne miejsce wyboru władz, siedzibę rajców miejskich, przestrzeń zaangażowania politycznego mieszczan czy jako wizualizację władzy po prostu, lecz również jako część złożonego miejskiego systemu przestrzennego, między kościołem a karczma, i jako - wprowadzając tu pojęcie „giełdy informacji” (Nachrichtenbörse) - przestrzeń przepływu informacji między sfera tajemnicy i sferą publiczna, „między dyskrecja akt radzieckich i charakterystyczną dla życia miejskiego jawnością"39.

${ }^{36}$ Zob. W. Behringer, B. Roeck, Das Bild der Stadt in der Neuzeit 1400-1800, München 1999; Imago urbis. L'immagine della città nella storia d'Italia. Atti del Convegno internazionale, Bologna 5-7 IX 2001, red. F. Bocchi, R. Smurra, Roma 2003; F. Opll, Bild und Wahrnehmung der Stadt, Linz 2004 (Beiträge zur Geschichte der Städte Mitteleuropas, 19); Das Bild und die Wahrnehmung der Stadt im Hanseraum im Mittelalter und in der frühen Neuzeit, red. R. Czaja, Torun 2004; Bild und Wahrnehmung der Stadt, red. P. Johanek, Wien-Köln-Weimar 2012 (Städteforschung, Seria A, 63).

${ }^{37}$ Międzynarodowa Komisja Historii Miast (Commission internationale pour l'histoire des villes; www.historiaurbium.org) zajmuje się tym tematem od 2011 r., zob. program konferencji w Sibiu/Hermannstadt we wrześniu 2011 r. (http://www.historiaurbium.org/english/SibiuConferenceProgram2011.pdf; 22 IV 2013) i w Pradze we wrześniu 2012 r. (http://www.historiaurbium.org/english/Prague\%20Program.pdf; 22 IV 2013).

${ }^{38}$ Międzynarodowa Komisja Historii Miast zajmowała się również tą problematyką podczas posiedzeń generalnych w Zagrzebiu, Londynie i Lecce. Niektóre referaty zostały opublikowane, zob. Towns and Communication, t. 1: Communication in Towns, red. N. Budak, Zagreb 2009; t. 2: Communication between Towns, red. H. Houben, K. Toomaspoeg, Galatina 2011 (Università del Salento. Dipartimento dei Beni delle Arti e della Storia. Saggi e testi, 45).

${ }^{39}$ M. Scheutz, Multifunktionalität der Rathäuser..., s. 22. 
Od niedawna powstaja na uniwersytetach prace dyplomowe, wśród których jako przykład dla Austrii można przytoczyć ukończona w $2001 \mathrm{r}$. dysertację poświęcona ratuszom w Górnej i Dolnej Austrii do 1848 r. ${ }^{40}$ Dzięki szeroko zakrojonej inicjatywie, Verein für Geschichte der Stadt Wien zorganizowało jesienią 2011 r. konferencję, której wnioski mogły ukazać się rok później drukiem dzięki zaangażowaniu pracowników Wiedeńskiego Archiwum Miejskiego i Krajowego, będącego siedziba wyżej wymienionego stowarzyszenia, jak również dzięki samemu Martinowi Scheutzowi. Praca ta, zatytułowana Rathäuser als multifunktionale Räume der Repräsentation, der Parteiungen und des Geheimnis$s e s^{41}$, porusza zagadnienia wychodzące znacznie poza granice tego, co rozumiane jest jako historia sztuki. Zawarte w niej artykuły zajmuja się nie tylko terytorium Austrii, ale znajdujemy również przykłady z małych miast w Hesji, ze Szwajcarii, z Czech i Węgier. Monumentalnemu wiedeńskiemu ratuszowi przy Ringstraße, nierozerwalnie zwiazanemu z era mieszczańskiego liberalizmu i w swych gotyckich formach nawiązującemu do wzorców flandryjskich, poświęcono większy blok studiów. Poglądy historyków jak i historyków sztuki przedstawione sa przez Martina Scheutza i Stephana Albrechta, a przytoczona przez nich bibliografia stanowi znakomity przegląd literatury przedmiotu, oferując przy tym klucz do jej zrozumienia. Karl Fischer, prezes Stowarzyszenia Miłośników Historii Wiednia, który dołączył do pracy „próbę syntezy”, sformułował precyzyjnie znaczenie, jakie ma ratusz dla miasta, powołując się na slogan wykreowany w 1986 r. przy okazji referendum w sprawie ustanowienia stolicy Dolnej Austrii, a mianowicie: „Miasto bez ratusza jest jak gulasz bez sosu!" ${ }^{42}$.

Nic dodać, nic ujaćc. Niech slogan ten będzie wezwaniem do dalszego historycznego podążania otwarta już droga badań nad zjawiskiem ratusza, a w szczególności do studiów porównawczych wykraczających poza granice terytorialne i czasowe.

Ttum. z niem. Roman Bator, konsultacja naukowa Halina Manikowska

${ }^{40}$ A.M. Seiler, „Die Entwicklung der Rathäuser in Nieder- und Oberösterreich von den Anfängen bis 1848", niepublikowana praca dyplomowa (Wien 2001).

${ }^{41}$ Jak w przyp. 19.

${ }^{42}$ K. Fischer, Versuch einer Synthese, w: Rathäuser als multifunktionale Räume..., s. 423 . 


\section{Bibliografia}

Albrecht S., Mittelalterliche Rathäuser in Deutschland. Architektur und Funktion, Darmstadt 2004.

Behringer W., Roeck B., Das Bild der Stadt in der Neuzeit 1400-1800, München 1999.

Binding G., Rathaus, w: Lexikon des Mittelalters, t. 7, Stuttgart-Weimar 1999.

Czeike F., Das Rathaus, Wien-Hamburg 1972 (Wiener Geschichtsbücher, 12).

Delling R., Deutsche Rathäuser, Frankfurt am Main 1958.

Grisebach A., Das deutsche Rathaus der Renaissance, Berlin 1907.

Isenmann E., Die deutsche Stadt im Mittelalter 1150-1550, Wien-Köln-Weimar 2012.

Opll F., Das älteste Wiener Rathaus, „Jahrbuch des Vereins für Geschichte der Stadt Wien" 46, 1990, s. 107-122.

Opll F., Bild und Wahrnehmung der Stadt, Linz 2004 (Beiträge zur Geschichte der Städte Mitteleuropas, 19).

Österreichischer Städteatlas, t. 1-10, red. F. Czeike, R. Banik-Schweitzer, F. Opll, A. Weigl, Wien 1982-2008. DVD (Arcanum Adatbázis Kft., Budapest [2009]).

Public Buildings in Early Modern Europe, red. K. Ottenheym, M. Chatenet, K. de Jonge, Turnhout 2010 (Architectura Moderna, 9).

Rathäuser als multifunktionale Räume der Repräsentation, der Parteiungen und des Geheimnisses, red. S.C. Pils, M. Scheutz, C. Sonnlechner, S. Spevak, Innsbruck-Wien-Bozen 2012 (Forschungen und Beiträge zur Wiener Stadtgeschichte, 55).

Roeck B., Rathaus und Reichsstadt, w: Stadt und Repräsentation, red. B. Kirchgässner, H.-P. Becht, Sigmaringen 1995 (Stadt in der Geschichte, 21), s. 93-114.

Stadtgründung und Stadtwerdung. Beiträge von Archäologie und Stadtgeschichtsforschung, red. F. Opll, Linz 2011 (Beiträge zur Geschichte der Städte Mitteleuropas, 220). 
Ferdinand Opll

The Town Hall as the focus of the spatial and political system in the city's development: considerations and references to relevant German and Austrian research since 1990

(Summary)

The article starts with the analysis of respective definitions and considerations regarding the term Rathaus in different languages (German, Italian, English and French). Subsequently the origins of town-halls are taken into closer consideration, a topic which - seen from the standpoint of modern city-marketing - plays a decisive role for the "ranking" of towns. As a synonym for the evolution of civic and urban liberties in Italy as well as north of the Alps the chronology of the evolution of town-halls as well as their topographical placement within the urban pattern are of greatest importance. More explicit considerations are given with regard to town-halls in Austrian towns. An excellent basis for this analysis is the data provided by the series of more than 60 volumes of the Österreichischer Städteatlas (edited 1982-2013). In the end an overview to the respective research with hints to some deficits and possibilities for further investigation is given. It should especially be indicated that the "Rathaus"-topic can and should play a much greater role within actual trends of research ("spatial turn").

Key words: town hall; Austrian towns; Middle Ages, early modern times; spatial turn; historical research in Austria. 